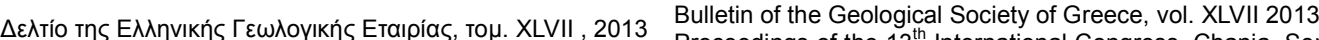

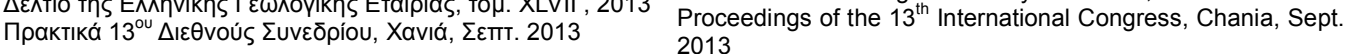

\title{
ASSESSMENT OF THE SUSCEPTIBILITY OF THE COAST OF ASTYPALAEA ISLAND (S.E. AEGEAN SEA) TO SEA- LEVEL RISE
}

\author{
Papoulia M. ${ }^{1}$, Karymbalis E. ${ }^{2}$, Gaki-Papanastassiou K. ${ }^{1}$ and Maroukian H. ${ }^{1}$ \\ ${ }^{I}$ Department of Geography-Climatology, Faculty of Geology and Geoenvironment, National and \\ KapodistrianUniversity of Athens, Greece, papoulia.m@gmail.com, gaki@geol.uoa.gr, \\ maroukian@geol.uoa.gr \\ 2DDepartment of Geography, Harokopio University, Athens, Greece, karymbalis@hua.gr
}

\begin{abstract}
The aim of this paper is the classification of the coast of Astypalaea Island (S.E. Aegean Sea) according to its susceptibility to an anticipated future sea-level rise, using the Coastal Sensitivity Index (CSI), and utilizing GIS technology. This index allows the following six physical variables: geomorphology, coastal slope, relative sea-level rise rate, shoreline erosion or accretion rate, mean tidal range and mean wave height, to be related in a semi-quantitative manner. Each variable is ranked on the basis of its potential contribution to physical changes on the coast as sea-level rises. Following the CSI calculation, a map is produced for the coastline of the island. This map showed that an extensive length of the coast $(121.5 \mathrm{~km}$, corresponding to $84.6 \%$ of the island's coastline) is characterized as very low and low sensitive. Only $12.1 \mathrm{~km}$ of the coast, corresponding to $8.5 \%$ of the entire coastline, is characterized as very highly and highly sensitive to sea-level rise, primarily due to the low topography and the presence of highly erodible geological formations and landforms. Areas of high and very high CSI values host socioeconomically important land uses and activities as well as environmentally protected areas.
\end{abstract}

Key words: Coastal Sensitivity Index (CSI), coastal geomorphology.

\section{Пврі́ $\eta \psi \eta$}

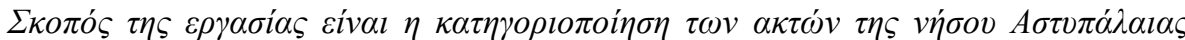

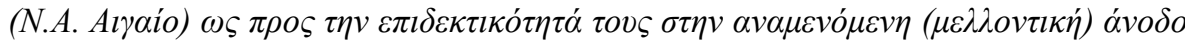

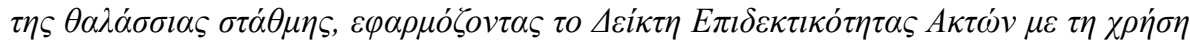

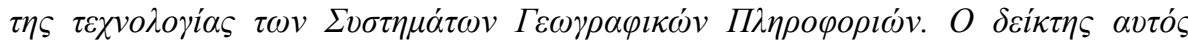

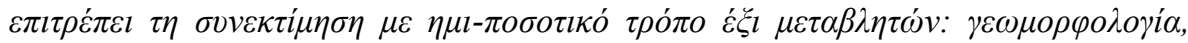

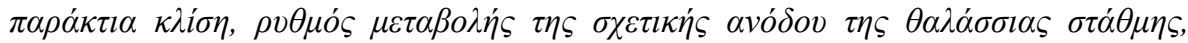

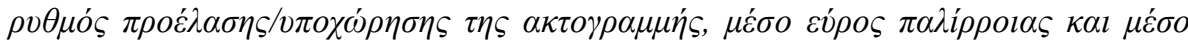

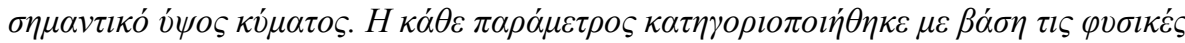

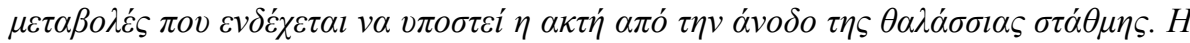

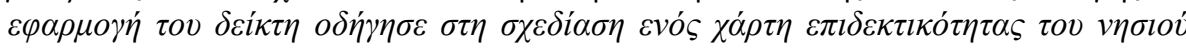

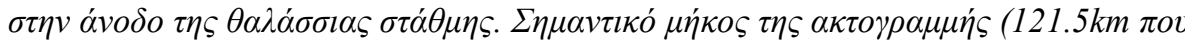




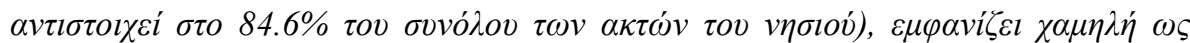

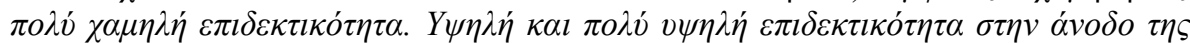

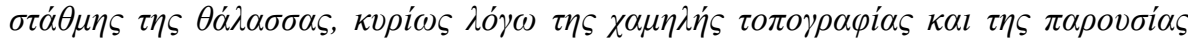

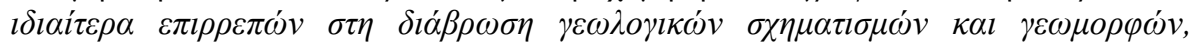

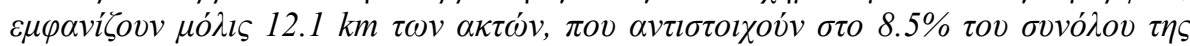

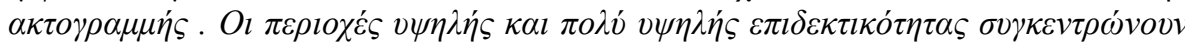

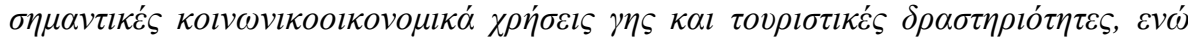

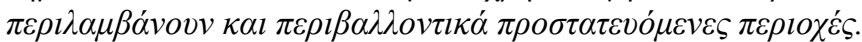

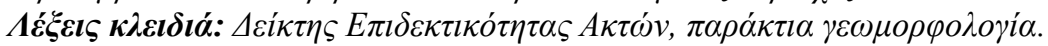

\section{Introduction}

The global average temperature has increased over the past century. Although the global warming in the previous century was estimated to be $0.8^{\circ} \mathrm{C}$, the rise in temperature in the last 30 years alone was $0.6^{\circ} \mathrm{C}$ at a rate of $0.2^{\circ} \mathrm{C}$ per decade as greenhouse gases became the dominant climate forcing (Rosenzweig et al., 2008). Perhaps the most commonly recognized impact of global warming is the eustatic rise in sea- level due to the thermal expansion of seawater and the addition of ice- melt water (Allen et al., 2006). The IPCC report of 2007 predicted that global sea- level will rise at least $59 \mathrm{~cm}$ by 2100 .

Recent projections of global sea- level rise due to climate change have generated an interest in coastal science to determine the response of coastlines to sea- level change. Various approaches have been proposed to predict the evolution of the coastal zone under the influence of anticipated sea-level rise. Each approach has its shortcomings or can be invalid for certain applications. The most important among these methods include the extrapolation of historical data (predominantly concerning the shifting of the shoreline), the application of static inundation models or simple geometric models like the Bruun Rule application of sediment dynamics models and probabilistic simulation based on parameterized physical forcing variables (Thieler and Hammar- Klose, 1999). Although a viable totally quantitative prediction of the coastal response to the sea-level rise is not available, the relative susceptibility of different coastal environments to sea-level rise may be quantified taking into account information on coastal geomorphology, rate of sea-level rise and other related factors.

The aim of this paper is to classify the coastal zone of Astypalaea Island with respect to its sensitivity to the anticipated future sea- level rise, through the calculation of the Coastal Sensitivity Index (CSI), similar to the formula proposed by Thieler and Hammar- Klose (1999). Identifying sections of shoreline susceptible to long- term sea-level rise is necessary for more effective coastal zone management, to increase resilience, and to help reduce the impacts of climate change on both infrastructure and human beings. Similar CSI calculation approaches have already been applied in Greece for the Aegean Sea Coast (Alexandrakis et al., 2009) as well as in a more detailed scale for the coasts of northeast Attica (Chatsieleftheriou et al., 2010), Argolikos Gulf (Gaki-Papanastassiou et al., 2011) and the Gulf of Corinth (Nasopoulou et al., 2012; Karymbalis et al., 2012).

In this study, the term sensitivity (which means susceptibility) is used rather than vulnerability because the latter term generally refers to human vulnerability to particular hazards and therefore requests a consideration of socioeconomic factors such as population, infrastructure, etc.

\section{Study Area}

Astypalaea Island, the westernmost island of the Dodecanese group, 300km SE of mainland Greece, has an area of $96 \mathrm{~km}^{2}$ and a coastline of $143.5 \mathrm{~km}$ (Figure 1). 
The island has 1,310 inhabitants, (2011 Census). Along with numerous smaller uninhabited offshore islets (the largest of which are Syrna and Ofidoussa), it forms the municipality of Astypalaea which belongs to the Kalymnos regional unit. Astypalaea is an island that has suffered from coastal natural hazards in the past with most severe the 1956 AD southern Aegean Tsunami (Dominey-Howes et al., 2000; Okal et al., 2009).

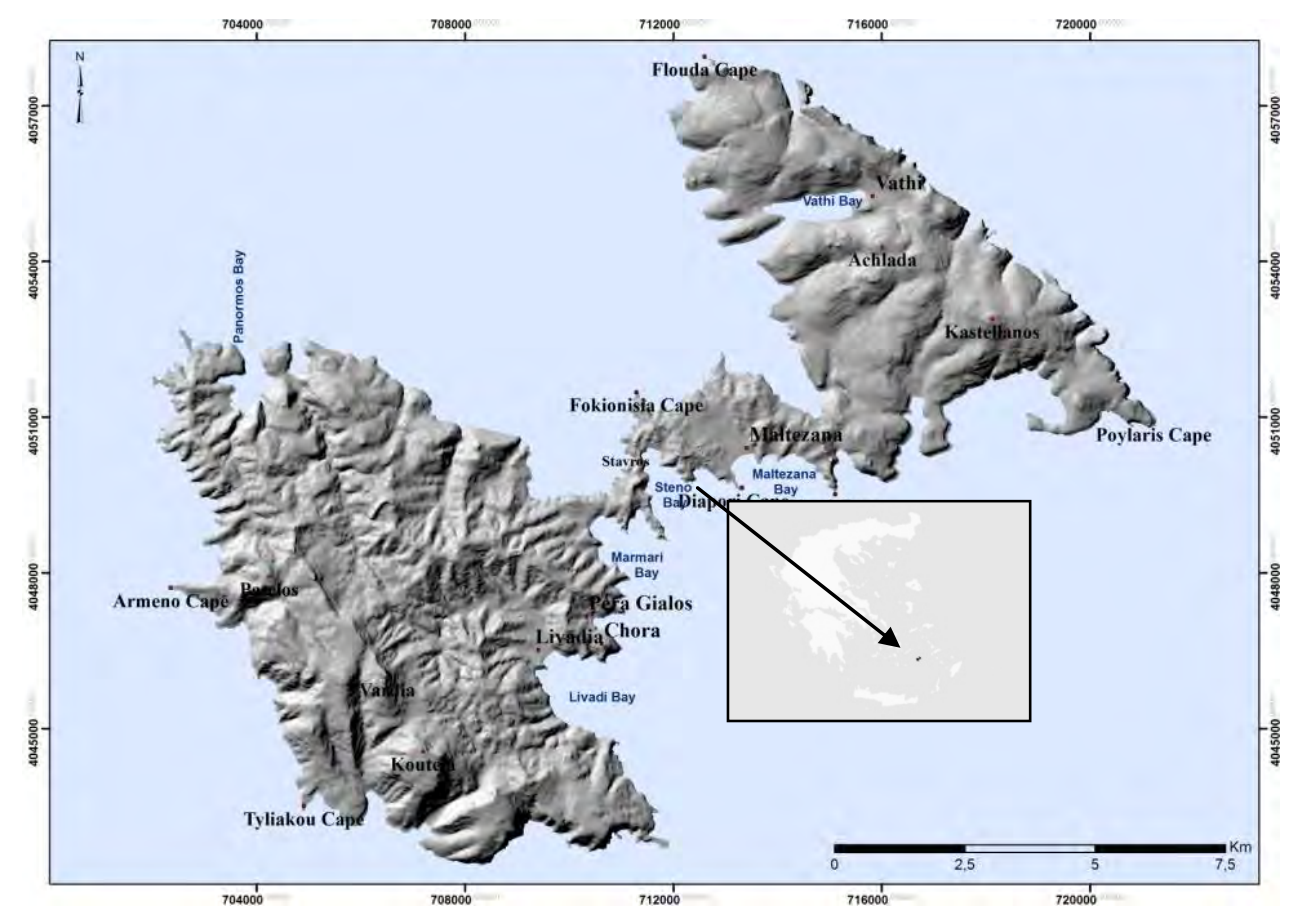

Figure 1 - Location and morphology of study area.

A small band of land of roughly $10 \mathrm{~km}$, almost separates the island into two sections: the inner and the outer island (hence the name butterfly island). The low-land of the island is centered on this band of land. The highest mountain top has an altitude of $481 \mathrm{~m}$ and is located in the western part of the island. Morphologically, the central part of the island is characterized by a gentle topography in whereas the western and eastern parts have a rough relief.

Astypalaea Island is situated between the Late Cretaceous - Eocene high-pressure metamorphic belt of the Cyclades and the Miocene high-pressure metamorphic belt of the External Hellenides. It is made up of weakly metamorphosed limestones and marls of the Tripolis geotectonic unit, which are overlain by Eocene to Oligocene flysch formations (IGME, 1986). The post Alpine formations include Quaternary deposits such as coastal sediments and calcarenites.

The $93.6 \%$ of the coastline of Astypalaea consists of coastal cliffs. Nearly $14.22 \%$ is occupied by rocky cliffs with slope greater than 30 degrees, $46.8 \%$ of the coastline is made of medium cliffs (slope values between 10 and 30 degrees) and the rest is occupied by rocky cliffs with slope less than 10 degrees. Apart from cliffs, there are also other rocky coastal landforms on the island such as sea caves and coastal benches. Almost all the beaches of the island are characterized as pocket beaches and consist of cobble, pebbles and rarely sands. Pocket beaches are located mainly in Maltezana, Livadia and Panormos Bays.

Astypalaea has been selected s a case study for the application of the Coastal Sensitivity Index mainly due to the geomorphic variation in coastal environments in addition to the prevailing socioeconomically important land uses and activities of the island such as agriculture and tourism. 


\section{Methodology and Data Collection}

The CSI estimated in this study is a modification of the Coastal Vulnerability Index proposed by Thieler and Hammar- Klose (1999), which modified the original index produced by Gornitz et al. (1994). This index allows six variables to be related in a quantifiable manner to express the relative sensitivity of the coast to physical changes due to future sea- level rise. The CSI is calculated as the square root of the product of six variables divided by their total number (six) (equation 1). The variables are ranked from 1 to 5 according to table 1 , with a rank of 1 , indicating very low sensitivity and a rank of 5 indicating very high sensitivity. For some of the variables, the ranges of sensitivity ranking proposed by Karymbalis et al. (2012) specifically for the coastal environment of Greece are taken into consideration. The six variables are: geomorphology, coastal slope, historic shoreline change, relative sea level rise rate, mean tidal range and mean significant wave height.

\section{Equation 1- Formula for CSI calculation}

$$
\mathrm{CSI}=\sqrt{ }(\mathrm{a} * \mathrm{~b} * \mathrm{c} * \mathrm{~d} * \mathrm{e} * \mathrm{f}) / 6
$$

Data concerning the geomorphology variable were derived from detailed (at the scale of 1:5,000) field coastal geomorphological mapping. Since this variable also represents the bedrock outcropping along the shoreline, data for the rock types were interpreted from the geological map of the island at a scale of 1:50,000 published by the Greek Institute of Geology and Mineral Exploration (IGME, 1986). In order to estimate the coastal slope (in percentage), a slope map of the coastal zone was created with the use of the detailed 1:5,000 topographic maps of the area. By using this map as the main elevation source, the digital elevation model (DEM), of the coastal zone was created. Next for the zone, the slope map was implemented within ArcGis spatial analysis extension environment, and the map of slope zones (according to table 1) was produced. Finally, for the assignment of the proper slope categorization to each coastline segment, the intersection of slope zones with the coastline was performed. Mean shoreline erosion or accretion rates were obtained from interpretation of aerial photos of the island taken in 1986 and 2009 respectively.

Table 1- Ranges for sensitivity ranking of the six variables.

\begin{tabular}{|l|c|c|c|c|c|}
\hline \multirow{2}{*}{ VARIABLES } & \multicolumn{5}{|c|}{ Categories } \\
\cline { 2 - 6 } & $\mathbf{1}$ & $\mathbf{2}$ & $\mathbf{3}$ & $\mathbf{4}$ & $\mathbf{5}$ \\
\hline & $\begin{array}{c}\text { rocky } \\
\text { cliffed } \\
\text { coasts } \\
\text { (limestone } \\
\text { cliffs) }\end{array}$ & $\begin{array}{c}\text { medium } \\
\text { cliffs } \\
\text { flysch } \\
\text { cliffs) }\end{array}$ & $\begin{array}{c}\text { low cliffs } \\
\text { (calcarenite cliffs) }\end{array}$ & $\begin{array}{c}\text { cobble } \\
\text { beaches }\end{array}$ & $\begin{array}{c}\text { sandy } \\
\text { beaches }\end{array}$ \\
\hline $\begin{array}{l}\text { Shoreline erosion (- } \\
\text { /accretion (+) rate m/year }\end{array}$ & $>(+2.0)$ & $\begin{array}{c}(+2.0)- \\
(+1.0)\end{array}$ & $(+1.0)-(-1.0)$ & $(-2.0)-(-1.0)$ & $<(-2.0)$ \\
\hline Coastal slope (\%) & $>12 \%$ & $9-12 \%$ & $6-9 \%$ & $3-6 \%$ & $<3 \%$ \\
\hline $\begin{array}{l}\text { Relative sea-level rise } \\
\text { (mm/year) }\end{array}$ & $<1,8$ & $1,8-2,5$ & $2,5-3,0$ & $3,0-3,4$ & $>3,4$ \\
\hline Mean wave height $(\mathrm{m})$ & $<0,3$ & $0,3-0,6$ & $0,6-0,9$ & $0,9-1,2$ & $>1,2$ \\
\hline Mean tide range $(\mathrm{m})$ & $>6,0$ & $4,0-6,0$ & $2,0-4,0$ & $1,0-2,0$ & $<1,0$ \\
\hline Sensitivity & Very low & Low & Moderate & High & Very high \\
\hline
\end{tabular}

Although relative sea- level change is the combination of both the global eustatic sea-level rise as well as local isostatic and/or tectonic land movements, for this study this variable includes only the 
eustatism component. This is because no recent local tide gauge measurements of the relative sealevel change or published information concerning the slip rates of the faults of the broader area of the island were available. Mean tidal range was deduced from published information (Tsimplis, 1994). The mean annual values of significant wave height have been abstracted from the Wave and Wind Atlas of the Hellenic Seas (Soukisian et al, 2007) which is based on offshore measurements for the time period between 1999 and 2007 (POSEIDON program).

To obtain a preliminary assessment of the impacts of the anticipated sea-level rise on socioeconomic activities, land cover of the coastal zone was identified utilizing the relevant map of the Corine 2000 Land Cover Program (table 2). Seven land cover categories were recognized, including urban areas, natural vegetation, cultivations etc. Land cover classes were compared with areas of higher CSI values, which represent the highly and very highly sensitive segments of the shoreline.

GIS software ArcGis (ver. 10.0), provided the platform for the coastal mapping and calculation of the index. For each variable the entire coastline of the island is segmented into five sensitivity classes, and a sensitivity rank number is assigned to each segment of the coast indicating the sensitivity level in terms of the given variable. The method of computing CSI in this study is similar to that applied by Pendelton et al (2005) and Thieler and Hammar- Klose (1999). In order to display the results of the index derived from integration of the variables, a template of segments has been derived for the coast. The segment-based template has been used to store and portray data for each of the variables in an attribute table (in vector format using shapefiles in ArcGis), for adjacent segments along the coast. For each of the six variables, a ranking on a scale of 1-5 was assigned to each segment (with rank 1 representing very low sensitivity and rank 5 indicating very high sensitivity) following the classification scheme outlined in table 1 . The final CSI map generated combining all the variables, showed 503 segments of the coast each having a unique identity in its corresponding attribute table. Another field is added to this attribute table for the CSI formula so that the system generated the CSI values for all the coastline segments of the island. The resulting output of CSI values were categorized into five classes by applying the natural breaks classification method such that the discrete index values of coastline segments are ranked in terms of their magnitude for the construction of the final CSI zonation map.

Table 2 - Shoreline segments' length and corresponding percentage of the seven land cover categories that occupy the five sensitivity classes along the coast of Astypalaea Island (land cover data obtained from Corine, 2000).

\begin{tabular}{|c|c|c|c|c|c|c|c|c|c|c|}
\hline \multicolumn{11}{|c|}{ Sensitivity } \\
\hline \multirow{2}{*}{$\begin{array}{l}\text { LAND USE } \\
\text { TYPES }\end{array}$} & \multicolumn{2}{|c|}{ Very low } & \multicolumn{2}{|r|}{ Low } & \multicolumn{2}{|c|}{ Moderate } & \multicolumn{2}{|r|}{ High } & \multicolumn{2}{|c|}{ Very high } \\
\hline & $\%$ & $\mathrm{Km}$ & $\%$ & $K m$ & $\%$ & $\mathrm{Km}$ & $\%$ & $K m$ & $\%$ & $\mathrm{Km}$ \\
\hline Natural grassland & 78,40 & 87,35 & 69,43 & 6,94 & 74,25 & 7,39 & 79,82 & 8,51 & 19,96 & 0,31 \\
\hline Airport & 0,23 & 0,25 & - & - & - & - & - & - & - & - \\
\hline $\begin{array}{l}\text { Discontinuous } \\
\text { urban fabric }\end{array}$ & 0,72 & 0,80 & - & - & - & - & 0,84 & 0,09 & - & - \\
\hline $\begin{array}{l}\text { Sclerophyllous } \\
\text { vegetations }\end{array}$ & 19,74 & 22,00 & 28,84 & 2,88 & 23,55 & 2,34 & 13,36 & 1,42 & 15,29 & 0,24 \\
\hline $\begin{array}{l}\text { Complex } \\
\text { cultivation } \\
\text { patterns }\end{array}$ & 0,75 & 0,83 & 0,48 & 0,05 & 2,20 & 0,22 & 4,68 & 0,50 & 53,92 & 0,83 \\
\hline $\begin{array}{l}\text { Agricultural land, } \\
\text { with areas of na- } \\
\text { tural vegetation }\end{array}$ & 0,16 & 0,18 & 1,25 & 0,13 & - & - & 1,03 & 0,11 & - & - \\
\hline
\end{tabular}




\begin{tabular}{|l|r|r|r|r|r|r|r|r|r|r|}
\cline { 3 - 11 } $\begin{array}{l}\text { Non-irrigated } \\
\text { arable land }\end{array}$ & - & - & - & - & - & - & 0,26 & 0,03 & 10,82 & 0,17 \\
\hline Total & 100 & 111,43 & 100 & 10,0 & 100 & 9,95 & 100 & 10,66 & 100 & 1,54 \\
\hline
\end{tabular}

\section{Results}

\subsection{Variables}

The geomorphology variable is a non numerical one and expresses the relative response of different types of coastal landforms to sea- level rise (Gaki-Papanastassiou et al., 2011). It considers also the relative resistance of various geological formations occurring along the shoreline to marine erosion processes. Thus, it is ranked qualitatively according to the relative strength of the coastal landforms and rocks. The main coastal landforms of the study area identified during the field coastal geomorphological mapping were marine cliffs composed of various rock types such as limestones and flysch, as well as gravelly beaches. Marine cliffs represent the main landform of the island occupying a total length of $134.4 \mathrm{~km}$, which corresponds to $93.66 \%$ of the coastline. Cobble beaches occupy $5.4 \mathrm{~km}$ or $3.74 \%$ of the coastline while sandy beaches occupy $3.7 \mathrm{~km}$ or $2.6 \%$ of the total coastline (Figure 2). Most of the beaches on the island are recognized as pocket beaches. The different landforms recognized were classified as shown in the table of Figure 2.

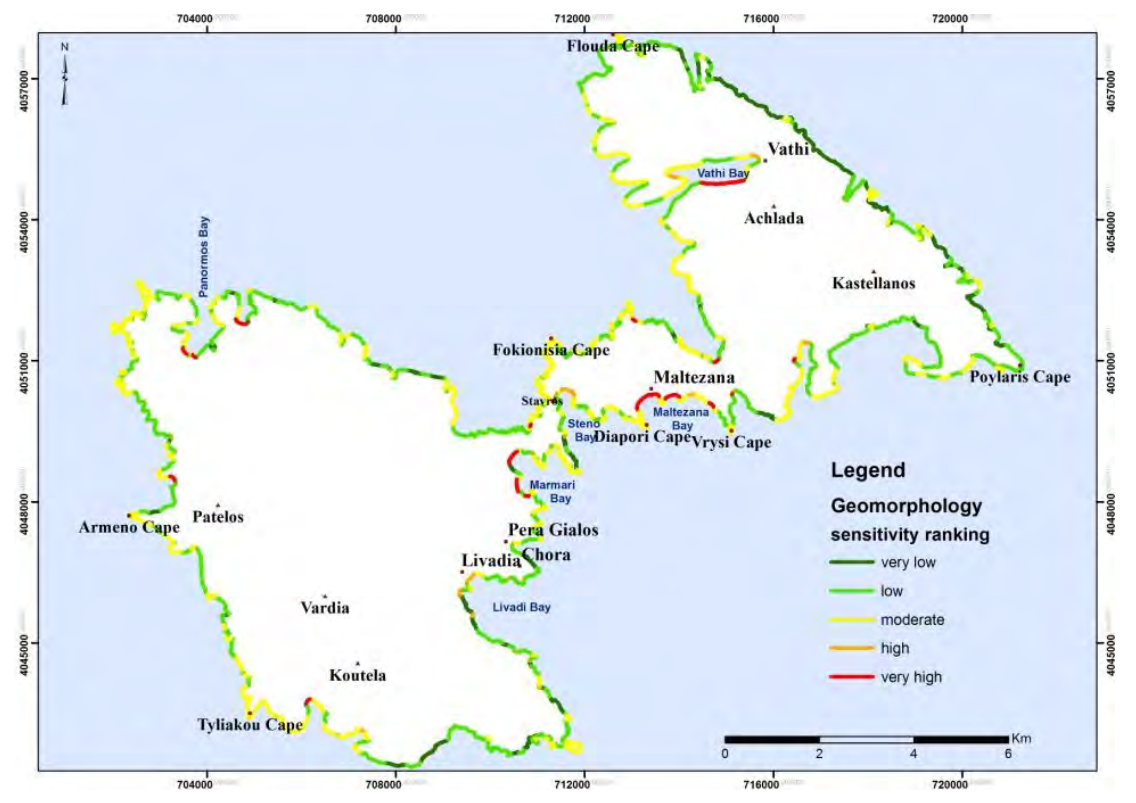

\begin{tabular}{|c|c|c|c|c|c|c|}
\hline Geomorphology & $\begin{array}{c}\text { rocky, cliffed } \\
\text { coasts }\end{array}$ & $\begin{array}{c}\text { medium } \\
\text { cliffs }\end{array}$ & $\begin{array}{c}\text { low } \\
\text { cliffs }\end{array}$ & $\begin{array}{c}\text { cobble } \\
\text { beaches }\end{array}$ & $\begin{array}{c}\text { sandy } \\
\text { beaches }\end{array}$ & total \\
\hline length $(\%)$ & 14,22 & 46,81 & 32,63 & 3,74 & 2,6 & 100 \\
\hline length $(\mathrm{km})$ & 20,4 & 67,2 & 46,8 & 5,4 & 3,7 & 143,5 \\
\hline Sensitivity & very low & low & moderate & high & very high & \\
\hline
\end{tabular}

Figure 2 - Table and map of sensitivity classification of the Astypalaea Island coastline according to the variable of geomorphology.

Among the considered variables, coastal slope is the main indicator of inundation risk. Determination of the regional coastal slope identifies the relative sensitivity of inundation and the 
potential rapidity of shoreline retreat as low-sloping coastal regions should retreat faster than steeper ones (Dwarakish et al., 2009). Regions with coastal slope less than 3\% were characterized as very highly sensitive, while cliffs with slope higher than $12 \%$ were of very low sensitivity. The $5.25 \%$ of the coastal zone, mainly in Maltezana and Livadi Bays, is low-lying and is characterized as highly susceptible to inundation. More than $79 \%$ of the coastline, which corresponds to more than $114 \mathrm{~km}$ of the total coastline, is characterized as very low sensitive. That's due to the presence of steep rocky cliffs (Figure 3).

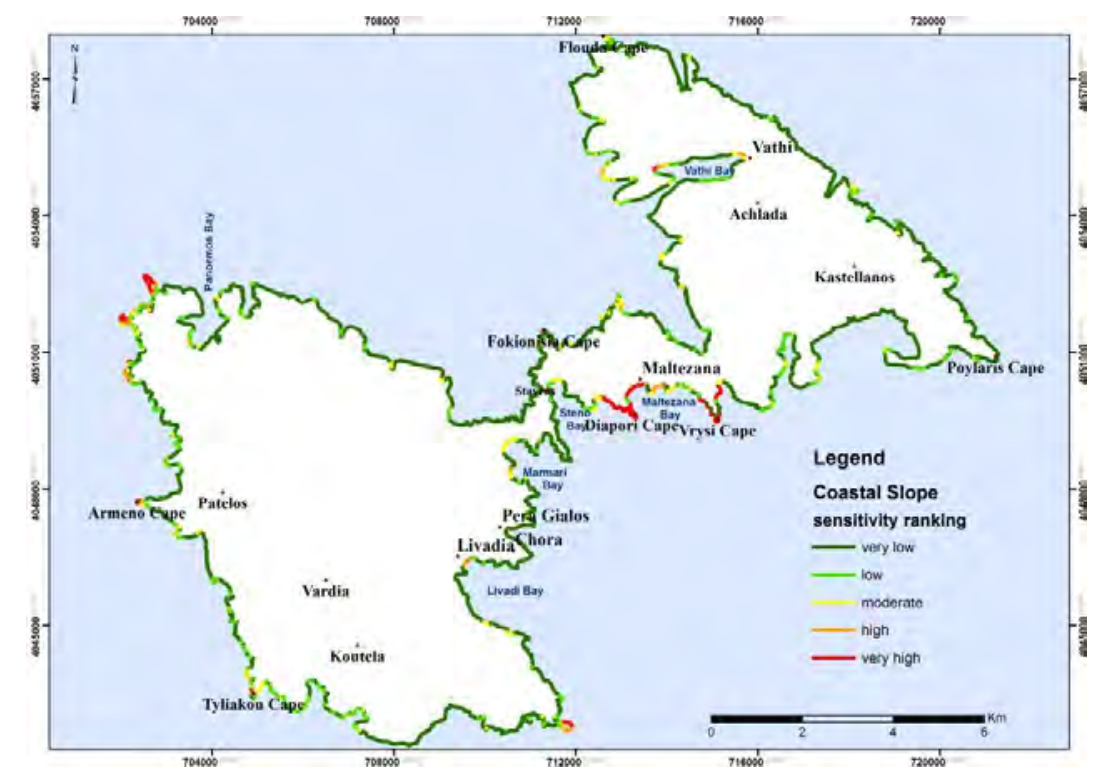

\begin{tabular}{|l|c|c|c|c|c|c|}
\hline Coastal Slope (\%) & $\mathbf{> 1 2 \%}$ & $\mathbf{1 2 - 9} \%$ & $\mathbf{9 - 6 \%}$ & $\mathbf{6 - 3} \%$ & $<\mathbf{3 \%}$ & total \\
\hline length (\%) & 79,5 & 5,6 & 5,34 & 4,31 & 5,25 & 100 \\
\hline length $(\mathrm{km})$ & 114,2 & 8,01 & 7,6 & 6,2 & 7,5 & 143,5 \\
\hline Sensitivity & very low & low & moderate & high & very high & \\
\hline
\end{tabular}

Figure 3- Table and map of sensitivity classification of the Astypalaea Island coastline according to the variable of coastal slope.

Coastline change rates in Astypalaea Island incorporate change rates from $+1 \mathrm{~m} /$ year of accretion (moderate sensitivity) to $-2 \mathrm{~m} /$ year of erosion (very high sensitivity) between 1986 and 2009. A shoreline length of $138.6 \mathrm{~km}$ (or $96.5 \%$ of the entire coastline) is relative stable (mean shoreline shifting rate within $\pm 1 \mathrm{~m} /$ year), while only $0.7 \mathrm{~km}$ (or $0.5 \%$ of the coastline) belongs to the class 5 - very high sensitivity (Table 1). Field coastal geomorphological mapping has verified that erosion is the main process along Maltezana beach in Maltezana Bay.

Relative sea- level change is considered to have the same value along the island's coastline. During the field survey submerged archaeological ruins of Late Roman- Early Byzantine age were found in Maltezana at about $50 \mathrm{~cm}$ below the present sea-level. Considering Lambeck's (1996) sealevel curve for the Aegean Sea it is obvious that submergence is the result of glacio-eustatic rise of sea-level. This indicates that eustatism is the main sea-level rise cause for the island since that period. Hence, this variable took the value $1.8 \mathrm{~mm} /$ year (low sensitive- class 2 in table 1 ), which is the mean eustatic global sea- level rise rate for the time period 1850-1950 (Solomon et al., 2007).

The variable of tidal range is linked to both inundation and erosion hazards (Gornitz, 1991). Micro-tidal coasts (tidal range $<2 \mathrm{~m}$ ), are at high risk and macro-tidal (tidal range $>4 \mathrm{~m}$ ) coasts are at low risk (Abuodha et al., 2010). The reason for this ranking is the potential influence of storms 
on coastal evolution and their impact relative to the tide range. A micro-tidal coast is essentially near high tide and therefore always at the greatest risk of inundation from storms. Astypalaea Island is a micro-tidal region with astronomical tide range $<0.15 \mathrm{~m}$ (Tsimplis, 1994). As such, the tidal range variable is ranked according to Thieler and Hammar- Klose (1999) with the value 5 (highly sensitive).

Wave height is proportional to the square root of wave energy, which is a measure of the capacity for erosion. The wave climate of the island is dominated by offshore significant wave heights of 0.6-1.2m, according to the output of the wave model (Poseidon program), which have been calibrated with the use of offshore field measurements (Soukisian et al., 2007). Hence, 30.78\% of the coastline along the southern part of the island (which corresponds to $44.2 \mathrm{~km}$ of the entire coastline) is considered to have moderate sensitivity and the rest of the coastline is considered to have high sensitivity.

\subsection{The CSI Values}

The calculated CSI values along the coastline of Astypalaea Island range between 3.87 and 25.81 . The median value of the index for the study area is 10.0 , and the standard deviation is 4.36 . CSI values above 17.89 are classified as indicative of very high sensitivity. Only $12.1 \mathrm{~km}$ of the coastline corresponding to $8.5 \%$ of the entire coastline, is characterized as very highly and highly sensitive to sea- level rise, primarily due to low topography and the presence of highly erodible geological formations and landforms. Nearly $111.5 \mathrm{~km}$ of the shoreline (or $77.60 \%$ of the total coastline) is characterized as very low sensitive with CSI values between 3.87 and 7.74 (Figure 4). Very highly sensitive areas are located in Maltezana Bay (Maltezana village), Vathi Bay and Livadia Bay (Livadia village). Highly sensitive areas are found in Marmari Bay, west of Diapori Cape and on the northwest part of the island.

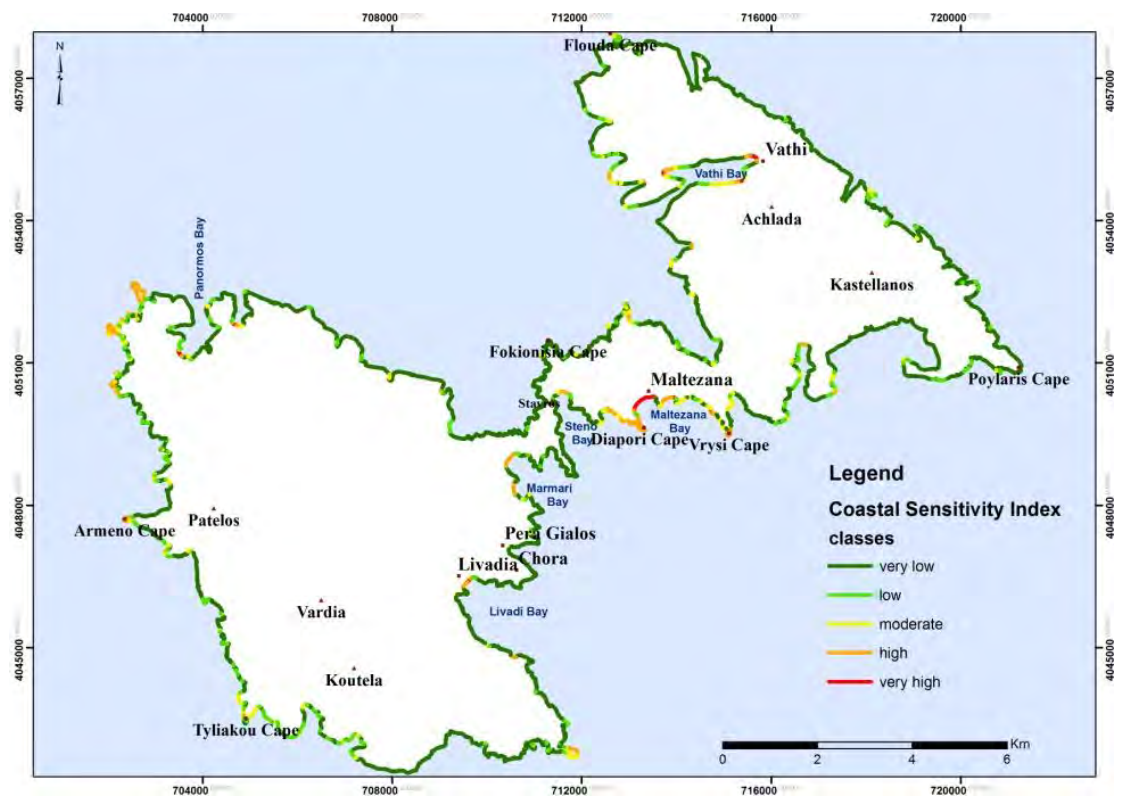

\begin{tabular}{|c|c|c|c|c|c|c|}
\hline \multicolumn{1}{|c|}{ CSI } & $\mathbf{3 , 8 7 - 7 , 7 4}$ & $\mathbf{7 , 7 5 - 1 1 , 1 8}$ & $\mathbf{1 1 , 1 9 - 1 4 , 1 4}$ & $\mathbf{1 4 , 1 5 - 1 7 , 8 8}$ & $\mathbf{1 7 , 8 9 - 2 5 , 8 1}$ & total \\
\hline length $(\%)$ & 77,6 & 6,97 & 6,93 & 7,43 & 1,07 & 100 \\
\hline length $(\mathrm{km})$ & 111,5 & 10 & 9,9 & 10,6 & 1,5 & 143,5 \\
\hline Sensitivity & very low & low & moderate & high & very high & \\
\hline
\end{tabular}

Figure 4- CSI Table and map of the Astypalaea Island coastline. 
In terms of the socio-economic impacts of the anticipated sea-level rise, most of the coastal villages as well as tourism activities and facilities are concentrated along very highly and highly sensitive coastal segments. Furthermore, areas of high and very high CSI values are environmentally protected by International Conventions.

\section{Conclusions}

In this study the relative sensitivity of Astypalaea Island to environmental changes due to future rise in sea-level is assessed with the calculation of the Coastal Sensitivity Index. Calculated CSI values along the studied coastline vary between 3.87 and 25.81. All variables incorporated into the CSI assessment can be considered factors contributing to coastal change. However, some variables make a larger contribution to index variability than others. Of the six variables, coastal slope and coastal geomorphology introduce the greatest variability to the CSI values. Among the other variables, shoreline change rate and mean significant wave height shows a small variation, while mean tidal range and relative sea level change have the same value along the coastline.

According to the criteria of coastal sensitivity, as defined in this study, an extensive segment of the island's coastline is of very low $(111.5 \mathrm{~km})$ and low $(10.0 \mathrm{~km})$ sensitivity. Only $12.1 \mathrm{~km}$, corresponding to $8.5 \%$ of the entire coastline, is characterized as very highly and highly sensitive to sea- level rise. These sections of the coast include low gradient coasts such as pocket beaches composed of unconsolidated sediments. These areas will be more susceptible to both erosion and inundation. Highly sensitive regions (CSI values $>14.15$ ), are Maltezana, Livadia and Vathi. The shoreline of Maltezana village is the most rapidly eroding part of the island with obvious results of erosion along the beach zone of the settlement.

A small length of the highly and very highly sensitive coastal zone is occupied by agricultural land while hosts the most important settlements of the island as well as tourism activities. It is estimated that during the summer period the population of the island is almost 13 times higher than the resident population.

This study provides a detailed spatial GIS database of topographic, geological and physiogeogrpahical characteristics, as well as land cover information for $143.5 \mathrm{~km}$ of shoreline, which could be renewed and expanded further in order to incorporate newly available data (e.g. storm surge), including new variables (e.g sediment budget), in the future for better results of a modified CSI. Besides the integration of CSI physical variables with further social cultural and economic factors may enable a broader assessment of the vulnerability of sections of the coast and the communities that live there.

\section{References}

Abuodha PAO. and Woodroffe C.D. 2010. Assessing vulnerability to sea-level rise using a coastal sensitivity index: a case study from southeast Australia, J Coast Conserv., 14, 189-205.

Alexandrakis G., Karditsa A., Poulos S., Gionis G. and Kampanis N. 2009. Assessment of the Aegean coasts vulnerability to sea-level rise, Proceedings of the $9^{\text {th }}$ Pan-Hellenic Symposium on Oceanography and Fisheries, Patras, 13-16 May, vol. I, 327-332.

Allen J.C. and Komar P.D. 2006. Climate controls on US west coast erosion processes, $J$ Coast Res., 22, 511-529.

Chatzieleftheriou M., Alexandrakis G., Poulos S., Gaki-Papanastassiou K. and Maroukian H. 2007. Assessment of vulnerability to a future sea-level rise of the $\mathrm{E}$ and NE coast of Attica, Proccedings of the $8^{\text {th }}$ Pan-Hellenic Geographical Conference, vol 1, 298-305.

Dominey-Howes D., Cundy A. and Croudace I. 2000. High energy marine flood deposits on Astypalaea Island, Greece: possible evidence for the AD 1956 southern Aegean tsunami, Marine Geology, 163, 303-315. 
Dwarakish G.S., Vinay S.A., Natesan U., Asano T., Kakinuma T., Ventakaramana K., Jagedeesha B. and Badita M.K. 2009. Coastal vulnerability assessment of the future sea-level rise in Udupi coastal zone of Karnataka state, west coast of India, Ocean and Coastal Management, 52, 467-478.

Gaki-Papanastassiou K., Karymbalis E., Poulos S., Seni A. and Zouva C. 2001.Coastal Vulnerability assessment to sea-level rise based on geomorphological and oceanographical parameters: the case of Argolikos Gulf, Peloponnese, Greece, Hellenic Journal of Geosciences, 45, 109-121.

Gornitz V., Daniels R.C., White T.W. and Birdwell K.R. 1994. The development of a coastal vulnerability assessment database: vulnerability to sea-level rise in the U.S. Southeast, $J$ Coast Res, Special Issue 12, 327-338.

Gornitz V. 1991. Global coastal hazards from future sea-level rise, Palaeogeography, Palaeoclimatology, Palaeoecology (Global and Planetary Change Section), 89, 379-398.

IGME 1986. Geological map of Greece, Astypalaea sheet, IGME, Athens.

Intergovernmental Panel on Climate Change, 2007. Climate Change 2007: The Physical Science Basis, Contribution of Working Group I to the fourth assessment report of the Intergovernmental Panel on Climate Change, Cambridge, United Kingdom and New York, N.Y., U.S.A., Cambridge University Press.

Karymbalis E., Chalkias Ch., Chalkias G., Grigoropoulou E., Manthos G. and Ferentinou M. 2012. Assessment of the sensitivity of the Gulf of Corinth (Peloponnese, Greece) to sea- level rise,Cent. Eur. J. Geosci., doi: 10.2478/s13533-012-0101-3.

Lambeck K. 1996. Sea-level change and shoreline evolution in Aegean Greece since upper Palaeolithic Time, Antiquity, 70, 588-611.

Nasopoulou I., Poulos S., Karymbalis E. and Gaki-Papanastassiou K. 2012. Coastal vulnerability assessment of the northern coast (Antirio-Eratini) of the western Corinth Gulf to the anticipated sea-level rise, Proceedings of the $10^{\text {th }}$ Panhellenic Symposium of Oceanography and Fishery (CD Rom).

Okal E.A., Synolakis C.E., Uslu B., Kalligeris N. and Voukouvalas E. 2009. The 1956 earthquake and tsunami in Amorgos, Greece, Geophys. J. Int., 178, 1533-1554.

Pendleton E.A., Thieler E.R. and Jefress S.W. 2005. Coastal vulnerability assessment of Golden Gate National Recretion Area to sea-level rise, USGS Open File Report, 2005-1058.

Rosenzweig C., Koroly D., Vicarelli M., Neofotis P., Wu Q., Casassa G., Menzel A., Root R.L., Estrella N., Sequin B., Tryjanowski P., Liu C., Rawlins S. and Imeson A. 2008. Attributing physical and biological impacts to anthropogenic climate change, Nature, 453, 353-357.

Soukisian T., Hatzinaki M., Korres G., Papadopoulos A., Kallos G. and Anadranistakis E. 2007. Wave and Wind Atlas of the Hellenic Seas, Hellenic Centre for Marine Research Publ., 300pp.

Thieler E.R. and Hammar-Klose E.S. 1999. National assessment of coastal vulnerability to sealevel rise, U.S. Atlantic Coast, USGS Open File Report, 99-593.

Tsimplis M.N. 1994. Tidal oscillations in the Aegean and Ionian Seas, Estuarine, Coastal and Shelf Science, 39, 201-208. 